\title{
Propylthiouracil: A Thyro-Suppressive as well as Haemato-Suppressive to Induce Agranulocytosis in Hyperthyroid Patients
}

Uzma Naz Shaikh ${ }^{1, *}$, Muhammad Ali Ghoto², Abdullah Dayo', Mudassar lqbal Arain², Rabia Parveen ${ }^{2}$

${ }^{1}$ Department of Pharmaceutics, Faculty of Pharmacy, University of Sindh, Jamshoro.

${ }^{2}$ Department of Pharmacy practice, Faculty of Pharmacy, University of Sindh, Jamshoro.

Authors' Contributions

1 Data Collection \& Processing, Data Analysis and/or Interpretation, Drafting of Manuscript. 2 Conception \& Study Design, Data Analysis and/or Interpretation, Critical Review. 3 Drafting of Manuscript, Critical Review.

4 Data Analysis and/or Interpretation, Drafting of Manuscript, Critical Review.

5 Data Collection \& Processing, Critical Review.

\section{Acknowledgement}

\section{Article info.}

Received: September 07, 2020

Accepted: January 25, 2021

Funding Source: Nil

Conflict of Interest: Nil

Cite this article: Shaikh UN, Ghoto MA, Dayo $A$, Arain MI, Parveen $R$, Anwar $R$. Propylthiouracil: A Thyro-Suppressive as well as Haemato-Suppressive to Induce Agranulocytosis in Hyperthyroid Patients. RADS J Pharm Pharm Sci. 2020; 8(4):188193.

*Address of Correspondence Author: shaikhuzma666@yahoo.com

\section{A B S TRAC T}

Background: Propylthiouracil (PTU) is a thyro-suppressive medication commonly used for the treatment of hyperthyroidism, but may cause agranulocytosis, which rises the mortality of patients.

Objective: To evaluate the prevalence of agranulocytosis in hyperthyroid patients after the use of Propylthiouracil. The aim of the current research is to access the drug utilization and investigation of PTU which aids in accessing rational therapy and other aspects related to the patient's safety.

Methodology: A cross- sectional study conducted from May 2016 to April 2017 at Liaquat University of Medical and Health Sciences, Hospital Hyderabad/ Jamshoro. 150 prescriptions were collected by non-probability consecutive sampling technique from the adults with Hyperthyroidism patients using Propylthiouracil. Thyroid function tests were conducted using Immunoassay Elecysis 2010. The blood profile tests were evaluated on Sysmex kx21. The collected data was evaluated using the Statistical Package for Social Sciences (SPSS).

Results: The data revealed that the propylthiouracil-induced agranulocytosis in 4 hyperthyroid patients ( $n=2$ males, $n=2$ females) and the prevalence of Propylthiouracil-induced agranulocytosis was $2.7 \%$.

Conclusion: It was observed that Propylthiouracil damages the hematopoietic stem cells and precursors of granulocytes in bone marrow can cause agranulocytosis.

Keywords: Agranulocytosis, hyperthyroidism, and propylthiouracil.

\section{INTRODUCTION}

Hyperthyroidism is an endocrinic disorder in which excessive thyroid hormones synthesize and release into the blood. Hyperthyroidism is mostly observed in female and worsen with passage of time. Hyperthyroidism found to be slightly more in whitish people rather than the other ethnic groups [1]. and the most common causes of over synthesis of thyroid hormones include Grave's disease (GD), multinodular toxic goiter (MNTG), and thyroid adenoma (TA). Hyperthyroidism can be managed by Radioactive lodine ablation (RAI), surgical removal of thyroid (thyroidectomy) and anti-thyroid drugs (propylthiouracil \& methimazole) [2]. Propylthiouracil (PTU) is a derivative of thiourea having anti-thyroid activity. This anti-thyroid medication is commonly recommended for Hyperthyroidism and also used to treat Grave's disease (GD) and Toxic multinodular goiter when the Methimazole and Radioactive lodine (RAI) treatment is contraindicated [3]. It inhibits the 
peripheral conversion of Thyroxine to Triiodothyronine. It is used prior to thyroid surgery or RAI ablation to treat hyperthyroidism. PTU also used to treat thyrotoxicosis crisis and thyroid storm in hyperthyroid patients [4]. Considerable side effects of Propylthiouracil (PTU) comprises Agranulocytosis, which is infrequent but life-threatening, in which total granulocyte count becomes less than $500 \mathrm{cell} / \mathrm{mm} 3$. Temperature, infection and sore throat are the basic manifestation of agranulocytosis [5]. Agranulocytosis generally develops within twelve weeks after the commence of PTU therapy, decreases the white blood cells $<1000$ cells mm3. The American Thyroid Association (ATA) guidelines suggested that all patients should examine blood profile tests before onset of therapy [6]. and it is also recommended to check blood profile for every 14 days during the 2 months of PTU therapy. Another very rare considerable hematological side effects of PTU is Aplastic anemia (AA) and hypoprothrombinemia [7]. Aplastic anemia (AA) is rare but severely dangerous side effect of propylthiouracil and also suppressed the bone marrow process for blood formation specially, White blood corpuscles in the body because white blood cells are the soldiers of our body which defense against the germs and pathogens. Although infectious diseases are the indication of agranulocytosis. Propylthiouracil prevented the process of myelopoiesis which induced granulocytopenia, thrombocytopenia and anemia. Carbimazole or Methimazole do not bound albumin protein as tightly as propylthiouracil bound. so, PTU has less chance to pass through the placenta and recommend in the first three months of pregnancy [8].

\section{MATERIALS AND METHODS}

Cross-sectional study was carried out to analyze the data of 150 hyperthyroid patients and entire data was gathered via Non-probability consecutive sampling technique who were diagnosed by hematological disorders at OPD and Pathology laboratory in Liaquat University Medical and Health Sciences (LUMHS), Hospital Hyderabad/Jamshoro, from May 2016 - April 2017 and their thyroid profiles and complete blood count were evaluated after medication of propylthiouracil. Permission (N0. DRUGS/1011) was taken from the institution's ethical board. Verbal consents were taken from all patients before collected data. All adults with hyperthyroidism who were taking (Propylthiouracil) were included and Patients of other endocrine disorder, autoimmune disease and all other diseases were excluded.

All data was evaluated by applying the latest version of Statistical Package for the Social Sciences (SPSS). Percentage \& frequency were determined for the qualitative variables; whereas, mean and (SD) standard deviation were computed for the quantitative variables. Independent sample t-test was exercised for the comparison of Thyroid profile \& blood disorders between men and women. The p-value considered significant if the outcome of difference was found $>0.05$.

\section{RESULTS}

Out of 150 patients, 144 (76\%) were females and 36 $(24 \%)$ were males. The overall mean age was $37.44 \pm 14.82$ years. Patients were categorized into four groups, age group 16-30 years 33 (22\%) patients, age group 31-45 years $58(38.7 \%)$ patients presenting the highest out of total, age group 46-60 years $37(24.66 \%)$, age group $61-75$ years 22 (14.6\%) patients shown in Figure 1.

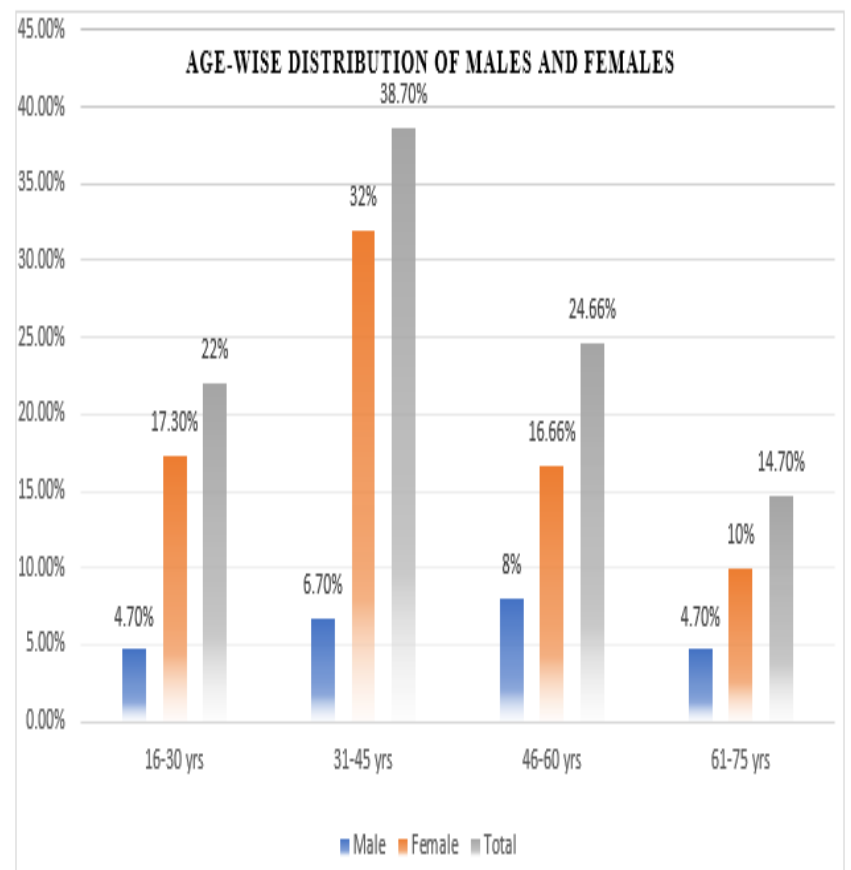

Figure 1. Age-wise distribution between males and females.

Most common presenting sign and symptoms were blurred vision (ophthalmopathy) $78(52 \%)$, sore throat $123(82 \%)$, and fever 120 (80\%) shown in Figure 2. 


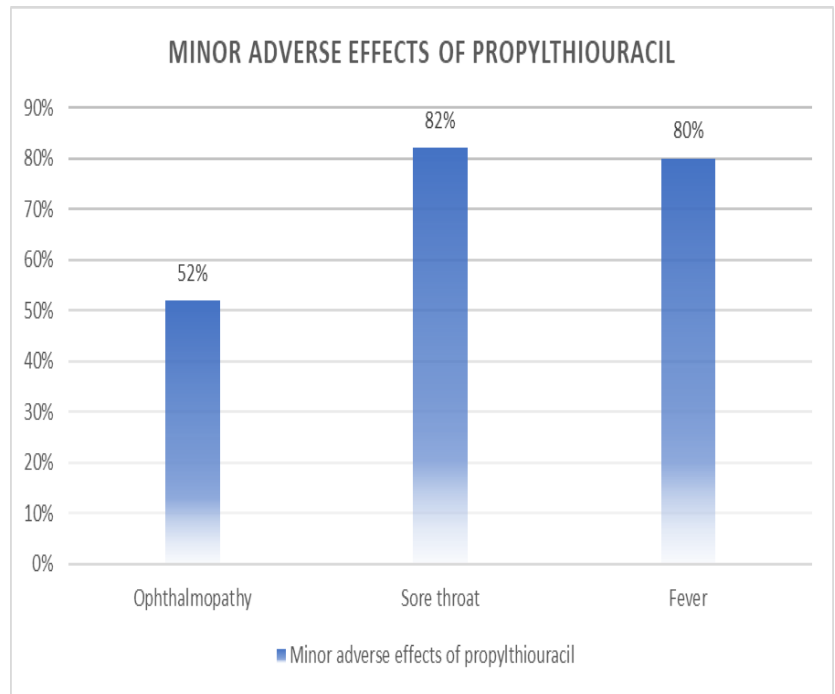

Figure 2. Minor Adverse effects of Propylthiouracil in hyperthyroid patients.

Propylthiouracil (PTU) associated changes observed in WBCs (Leucocytes), Red Blood Corpuscles (erythrocytes), and Platelets (Megakaryocytes), there were noticeable reduction in total leukocyte count (TLC ) 2(1.33\%)in men along with mean $6.2 \pm 0.55$ $10^{\wedge} 3 /$ ul and $2(1.33 \%)$ in female with mean value $6.9 \pm 0.7710^{\wedge} 3 /$ ul, slightly decreased RBCs was also observed $6(4 \%)$ in male with mean value $11.73 \pm 0.33$ $\mathrm{gm} / \mathrm{dl}$ and $9(6 \%)$ in female with mean value $9.23 \pm 0.4$ $\mathrm{gm} / \mathrm{dl}$, and minor reduction in Thrombocytes were also reported $3(2 \%)$ in male with mean value $255.3 \pm 1510^{\wedge} 3 / \mathrm{ul}$ and $9(6 \%)$ in female with mean value $312 \pm 9.010^{\wedge} 3 /$ ul shown in Table 1. Out of total, $4(2.7 \%)$ patients were observed with agranulocytosis, $3(2 \%)$ patients reported in age group of $46-60 \mathrm{yrs}$ and $1(0.7 \%)$ hyperthyroid patient reported in age group 61-75 yrs. The slight change in RBCs and platelets is insignificance.

Agranulocytosis was reported in 4 patients, (all four patients were having sore throat), (3 patients with ophthalmopathy and 1 without ophthalmopathy), and (3 patients with temperature and 1 without temperature

Table 1. Comparison of Hematological Disorders in Males and Females Before and After the use of Propylthiouracil (PTU).

\begin{tabular}{|c|c|c|c|c|c|c|}
\hline Hemogram & $\begin{array}{l}\text { Reference } \\
\text { value }\end{array}$ & $\begin{array}{c}\text { Before PTU } \\
\text { therapy } \\
\text { Male }(n=36)\end{array}$ & $\begin{array}{c}\text { Before PTU } \\
\text { therapy } \\
\text { Female } \\
(n=114)\end{array}$ & $\begin{array}{c}\text { After PTU } \\
\text { therapy } \\
\text { Male }(n=36)\end{array}$ & $\begin{array}{c}\text { After } \\
\text { therapy } \\
\text { Female } \\
(n=114)\end{array}$ & P-value \\
\hline Hemoglobin & $\begin{array}{l}12-16 \\
\mathrm{gm} / \mathrm{dl}\end{array}$ & $13.62 \pm 0.36$ & $11.90 \pm 0.13$ & $11.73 \pm 0.33$ & $9.23 \pm 0.4$ & 0 \\
\hline Hematocrit & $36-48 \%$ & $32.3 \pm 2.4$ & $30.5 \pm 1.8$ & $30.3 \pm 2.8$ & $27.7 \pm 1.5$ & 0.01 \\
\hline R.B.C & $\begin{array}{l}4.3-5.9 \\
10^{\wedge} 6 / L\end{array}$ & $4.51 \pm 0.6$ & $4.13 \pm 0.8$ & $4.1 \pm 0.5$ & $3.7 \pm 0.9$ & 0.021 \\
\hline W.B.C & $\begin{array}{c}4-10 \\
10^{\wedge} 3 / \mathrm{UL}\end{array}$ & $7.52 \pm 0.35$ & $8.06 \pm 0.20$ & $6.2 \pm 0.55$ & $6.9 \pm 0.77$ & 0.19 \\
\hline $\begin{array}{c}\text { Neutrophils } \\
\text { granulocytes }\end{array}$ & $40-75 \%$ & $61.7 \pm 5.6$ & $59.6 \pm 5.9$ & $58.9 \pm 8.2$ & $59.2 \pm 7.3$ & 0.031 \\
\hline Lymphocytes & $20-45 \%$ & $28.1 \pm 3.4$ & $26.7 \pm 3.2$ & $27.1 \pm 4.3$ & $25.3 \pm 1.2$ & 0.001 \\
\hline Monocytes & $2-10 \%$ & $6.8 \pm 1.9$ & $6.2 \pm 2.1$ & $5.5 \pm 1.8$ & $5.2 \pm 2$ & 0.005 \\
\hline Eosinophils & $1-6 \%$ & $2.36 \pm 0.9$ & $2.2 \pm 1.0$ & $2.1 \pm 1.0$ & $2.2 \pm 0.9$ & 0.002 \\
\hline Basophils & $<1 \%$ & $0.366 \pm 0.07$ & $0.32 \pm 0.04$ & $0.33 \pm 0.08$ & $0.30 \pm 0.08$ & 0 \\
\hline Thrombocytes (PLT) & $150-400 \%$ & $268.2 \pm 13$ & $323 \pm 8.8$ & $255.3 \pm 15$ & $312 \pm 9.0$ & 0.001 \\
\hline Temperature (Temp) & $37 \dot{C}$ & $37.8 \pm 0.8$ & $38.2 \pm 1.2$ & $38.2 \pm 1.0$ & $38.9 \pm 1.5$ & 0.02 \\
\hline
\end{tabular}

All values have been expressed as means \pm SD (Standard deviation) 
Out of 150 patients, $16(10.7 \%)$ were hypothyroid and $43(28.7 \%)$ were hyperthyroid.

Thyroid profiles results before medication, TSH was normal in 33(22\%), low in 93(62\%) and high in 24 (16\%), results after PTU TSH was normal in 122 (83.3\%), low in 12 (8\%) and high in $16(10.7 \%)$ patients. Results before medication T3 value was normal in 45(30\%), low in 3(2\%) and high in 102 (68\%) patients and result after medication T3 value was normal in $91(60.7 \%)$, low in $16(10.7 \%)$ and high in $43(28.7 \%)$ patients whereas T4 results before medication was normal in $18(12 \%)$ Low were in 6 (4\%) and High were in $126(84 \%)$ and after medication T4 was normal in $102(68 \%)$ Low were in $16(10.7 \%)$ and High were in $32(21.3 \%)$ shown in Table 2. The overall mean of $\mathrm{TSH}(\mathrm{uU} / \mathrm{ml})$ was $(2.4 \pm$ $0.34)$, T3 $(\mathrm{ng} / \mathrm{ml})$ was $(1.41 \pm 0.13)$, and T4 (ug/dl) was $(8.94 \pm 0.42)$

Table 2. Comparison of Thyroid Profile (TSH, T3 \&T4) in Males and Females Before and After the Use of Propylthiouracil.

\begin{tabular}{|c|c|c|c|c|c|c|}
\hline $\begin{array}{c}\text { Thyroid } \\
\text { profile }\end{array}$ & $\begin{array}{c}\text { Reference } \\
\text { range }\end{array}$ & $\begin{array}{c}\text { Before PTU } \\
\text { medication } \\
\text { Male (n=36) }\end{array}$ & $\begin{array}{c}\text { Before PTU } \\
\text { medication } \\
\text { Female(n=114) }\end{array}$ & $\begin{array}{c}\text { After PTU } \\
\text { medication } \\
\text { Male (n=36) }\end{array}$ & $\begin{array}{c}\text { After PTU } \\
\text { medication } \\
\text { Female } \\
\mathbf{( n = 1 1 4 )}\end{array}$ & P-value \\
\hline $\mathbf{T S H}$ & $\begin{array}{c}0.27-4.2 \\
\mathrm{uU} / \mathrm{ml}\end{array}$ & $1.68 \pm 0.2$ & $3.25 \pm 0.7$ & $1.58 \pm 0.18$ & $3.19 \pm 0.5$ & 0.003 \\
\hline T3 & $\begin{array}{c}0.8-2.0 \\
\mathrm{ng} / \mathrm{ml}\end{array}$ & $1.55 \pm 0.19$ & $1.47 \pm 0.19$ & $1.45 \pm 0.17$ & $1.36 \pm 0.09$ & 0.661 \\
\hline $\mathbf{T 4}$ & $\begin{array}{c}5.1-14.1 \\
\text { ug/dl }\end{array}$ & $12.2 \pm 1.2$ & $11.80 \pm 0.2$ & $9.19 \pm 0.65$ & $8.70 \pm 0.19$ & 0.480 \\
\hline
\end{tabular}

All values have been expressed as means \pm SD (Standard deviation)

\section{DISCUSSION}

Hyperthyroidism is a clinical syndrome in which thyroid gland synthesize excessive amount of thyroid hormone and the most common cause is Grave's disease (GD). Propylthiouracil is recommended as a first choice of drug therapy for the management of hyperthyroidism because it suppresses the synthesis of thyroid hormones by stopping the oxidation process of iodine in thyrocytes of gland [9]. Propylthiouracil is a thyro-suppressive medication commonly used for the treatment of hyperthyroidism, but may cause agranulocytosis, which rises the mortality of patients. Advantages of PTU includes rapid symptomatic relief and inexpensive. Disadvantages are long course of therapy (12-18 months), high chance of occurrence of agranulocytosis.

A retrospective research was conducted at Northern Taiwan Medical Center (NTMC) out of four cases 2 patients reported agranulocytosis, temperature, sore throat and dysentery were common presenting signs of agranulocytosis [10]. In the present study out of 150 cases 4 patients reported agranulocytosis along with fever (80\%), sore throat (82\%) and ophthalmopathy $(52 \%)$ as a common presenting sign and symptoms of agranulocytosis.

It is most commonly observed in women rather than men and women-to-men ratio of ADT caused agranulocytosis was reported 10.4:1. In the current study the ratio of female and male with agranulocytosis was $2: 2$ or $1: 1$. In another similar study the ratio of female and male with agranulocytosis was 10.4:1, and most common sign and symptoms were fever (80\%), sore throat $(82 \%)$ and ophthalmopathy (52\%). The other most common sign and symptoms were fever $(92 \%)$, sore throat $(85 \%)$ and headache (8\%) [11] and in another study sore throat $(72.8 \%)$ and fever $(78.9 \%)$ were the common manifestation of agranulocytosis [12]. In the present study the 2 males and 2 females were reported agranulocytosis where fever $(80 \%)$, sore throat $(82 \%)$ and ophthalmopathy $(52 \%)$ were the common manifestation of agranulocytosis.

Propylthiouracil induced $0.3-0.6 \%$ agranulocytosis in hyperthyroid patients and hematopoietic destruction was mostly reported at the age of more than 60 years [13]. In present research, the prevalence of propylthiouracil related agranulocytosis $(2.7 \%)$ was 
more as compare to the previous research and most cases of agranulocytosis was observed at the age between 46 to 75 years.

The alteration of RBCs, WBCs \& PLT was reported in PTU-treated patients which may cause hypothyroidism (underactive thyroid) disturbed directly erythropoiesis may lead to agranulocytosis due to the suppression of bone marrow [14]. In the current study $16(10.7 \%)$ patients had hypothyroidism after the PTU treatment which may leads to agranulocytosis too.

Grave's ophthalmopathy is an optical indication of the autoimmunological process usually indicates excessive thyroid hormones, optical symptoms almost reported in $26-63 \%$ of adults [15]. whereas, in current study Graves' ophthalmopathy was observed in 78 $(52 \%)$ hyperthyroid patients, which is similar, to this study.

Agranulocytosis is a potentially fatal adverse effect occurred with PTU in 0.2 to $0.5 \%$ of patients. Majority of the agranulocytosis cases reported in 90 days after the commence of therapy. The patients should receive instruction from physicians and report if any symptoms observed such as pancytopenia temperature, sore throat/pharyngitis, diarrhea [16]. In recent study the potentially fatal side effects agranulocytosis was reported in $2.7 \%$ of patients and fever $(80 \%)$, and sore throat $(82 \%)$ was reported within 3 months after onset of therapy.

A retrospective study was conducted in China on 9690 patients clinically diagnosed agranulocytosis after the treatment of ATD. The mean age of patients was $( \pm S D$ standard deviation) $41.7 \pm 12.3$ years. Propylthiouracil-induced agranulocytosis within 4 weeks and worsen as the passage of time and Sore throat $(72.8 \%)$ and fever $(78.9 \%)$ were the commonest features observed when agranulocytosis was identified [17]. In present study the mean age of the patients with propylthiouracil-induced agranulocytosis was $37.44 \pm 14.82$ years. At the time of agranulocytosis diagnosed patients reported fever $(80 \%)$ and sore throat $(82 \%)$ as a commonest manifestation of agranulocytosis.

Propylthiouracil related agranulocytosis is uncertain and can be develop as soon as two weeks after onset of treatment or may be late up to 12 weeks. Advance age patients have greater chance of agranulocytosis has been noticed with more than 40 years in some studies, and it is thought to be mediated either by direct drug toxicity or immunologic reactions. PTU can easily penetrate to marrow of bones and disturb the oxygen $\left(\mathrm{O}_{2}\right)$ and glucose $\left(\mathrm{C}_{6} \mathrm{H}_{12} \mathrm{O}_{6}\right)$ utilization of white blood cells (WBCs) which may lead to agranulocytosis. Highest mortality rate of ATDinduced agranulocytosis has been noticed approximately $21.5 \%$ with clinical feature of temperature or pharyngitis/ sore throat as a common manifestation of agranulocytosis [18]. In current study all patients of ATD-induced agranulocytosis were observed in age between 46-75 years and the mortality rate was $2.7 \%$ and agranulocytosis occurred along with fever and sore throat.

Propylthiouracil induced immunological effects and reacted with completely mature white blood corpuscle and damage the cellular part of blood and hematopoietic stem cells production. The immunemediated process also known as a PTU- induced agranulocytosis.

\section{CONCLUSION}

The present study reveals that patients developed agranulocytosis after the administration of the propylthiouracil, which is rare but potentially lifethreatening and usually hard to predicate that which patients have tendency to develop agranulocytosis, therefore, a regular complete blood profile test is recommended for the early diagnosis of agranulocytosis. Severity of hyperthyroidism and dose of medicine (PTU) better be judge and selected based on symptoms. Agranulocytosis develops suddenly and eruptive, so this is suitable to obtain baseline leukocytes count prior to onset of therapy. Patients should be advised to inform the doctors instantly if sore throat and fever develops.

\section{REFERENCES}

1. Garmendia Madariaga A, Santos Palacios S, Guillén-Grima F, Galofré JC. The incidence and prevalence of thyroid dysfunction in Europe: a meta-analysis. J Clin Endocrinol Metab. 2014;99(3):923-31. doi: 10.1210/jc.20132409. Epub 2014 Jan 1.

2. Kravats I, Hyperthyroidism: Diagnosis and Treatment, Am Fam Physician 2016;93(5):363-70.

3. Bartalena L, Fatourechi V. Extrathyroidal manifestations of graves' disease: a 2014 update. J Endocrinol Invest2014;37(8):691-700 doi: 10.1007/s40618-014-0097-2. 
4. Singer PA, Cooper DS, Levy EG, Ladenson PW, Braverman LE, Daniels G, Greenspan FS, McDougall IR, Nikolai TF 1995 Treatment guidelines for patients with hyperthyroidism and hypothyroidism. Standards of Care Committee, American Thyroid Association. JAMA, 1995, 273(10):808-12

DOI: 10.1001/jama.1995.03520340064038.

5. Robinson J, Richardson M, Hickey J, James A, Pearce SH, Ball SG, et al. Patient knowledge of antithyroid drug-induced agranulocytosis. Eur Thyroid J 2014;3(4):245-51. doi: 10.1159/000367990

6. Bahn Chair RS, Burch HB, Cooper DS, Garber JR, Greenlee MC, Klein I, et al. Hyperthyroidism and other causes of thyrotoxicosis: management guidelines of the American thyroid association and american association of clinical endocrinologists. Thyroid 2011;21(6):593-646. doi: 10.1089/thy.2010.0417.

7. Azizi F, Malboosbaf R. Long-term antithyroid drug treatment: a systematic review and meta-analysis. Thyroid 2017;27(10):1223-31 doi: 10.1089/thy.2016.0652.

8. Chattaway JM, Klepser TB. Propylthiouracil versus methimazole in treatment of Graves' disease during pregnancy. Ann Pharmacother 2007;41(6):1018-22. doi: 10.1345/aph.1H535.

9. Hollowell JG, Staehling NW, Flanders WD, Hannon WH, Gunter EW, Spencer CA, et al. Serum TSH, T (4), and thyroid antibodies in the United States population (1988 to 1994): National Health and Nutrition Examination Survey (NHANES III) J Clin Endocrinol Metab. 2002;87(2):489-99. doi: 10.1210/jcem.87.2.8182.

10. Sun MT, Tsai $\mathrm{CH}$, Shih $\mathrm{KC}$, Antithyroid druginduced agranulocytosis, J Chin Med Assoc, 2009;72(8):438-41. doi: 10.1016/S17264901(09)70402-2.

11. Sheng $W H$, Hung $C C$, Chen $Y C$, Fang $C T$, Hsieh S M, Chang S C et al. Antithyroid- drug- induced agranulocytosis complicated by lifethreatening infections. QJM An International Journal of Medicine 1999;92(8):455-61. doi: 10.1093/qjmed/92.8.455.

12. Yang J, Zhu Y J, Zhong J J, Zhang J, Weng W W, Liu ZF, et al. ${ }^{1}$ Characteristics of Antithyroid DrugInduced Agranulocytosis in Patients With Hyperthyroidism: A Retrospective Analysis of 114 Cases in a Single Institution in China Involving 9690 Patients Referred for Radioiodine Treatment Over 15 Years. Thyroid 2016;26(5):627-33 doi: 10.1089/thy.2015.0439.

13. Mohan A, Joseph S, Sidharthan N, Murali D. Carbimazole-induced agranulocytosis. J Pharmacol Pharmacothera. 2015;6(4):228-30. doi: 10.4103/0976-500X.171881.

14. Duntas LH, Brenta G. A renewed focus on the association between thyroid hormones and lipid metabolism. Front Endocrinol (Lausanne). 2018; 9:511. doi: 10.3389/fendo.2018.00511.

15. Chattaway JM, Klepser TB. Propylthiouracil versus methimazole in treatment of Graves' disease during pregnancy. Ann Pharmacother. 2007; 41(6):1018-22. doi: 10.1345/aph.1H535.

16. Rabelo PN, Rabelo PN, Paula AF, Conceição SAD, Viggiano DPPO, Antunes DE, Jatene EM, Paula SLFM, Dias ML, Reis MAL. Propylthiouracilinduced agranulocytosis as a rare complication of antithyroid drugs in a patient with Graves' disease. Rev Assoc Med Bras (1992). 2019; 65(6):755-760. DOI: 10.3390/medicina56060290.

17. Yang J, Zhu YJ, Zhong J J, Zhang J, Weng WW, Liu ZF et al Characteristics of Antithyroid DrugInduced Agranulocytosis in Patients with Hyperthyroidism: A Retrospective Analysis of 114 Cases in a Single Institution in China Involving 9690 Patients Referred for Radioiodine Treatment Over 15 Years, Thyroid, 2016;(5):627-33. doi.org/10.1089/thy.2015.0439.

18. Cooper DS antithyroid drugs, $\mathrm{N}$ Engl $\mathrm{J}$ Med,200;352(9);905-17. doi: 10.1056/NEJMra042972. 